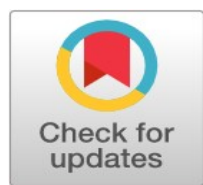

\title{
Brand equity affects brand loyalty of the bottled mineral drinking water in Thailand
}

\author{
Kittipa Wichailert $^{1^{*}}$, Khanchitpol Yousapornpaiboon ${ }^{2}$ \\ ${ }^{1,2}$ College of Graduate Study in Management, Khon Kaen University, Thailand
}

\author{
Keywords \\ Brand equity \\ Brand awareness \\ Brand association \\ Perceived quality of brand \\ Brand loyalty
}

Received: 15 June 2017

Accepted: 22 July 2017

Published: 21 August 2017

\begin{abstract}
This study focused on the brand equity that affects brand loyalty of the bottled mineral drinking water by integrating brand equity and brand loyalty models. This study adopted self-administered questionnaires to collect data and used quantitative data analysis. Four hundred of customers who drank the bottled mineral drinking water were collected. The sample was selected using purposive sampling method. The statistics used to analyze data were frequency, percentage, mean, standard deviation, and multiple regression analysis. The result indicates a mediating relationship among the dimensions of brand equity and brand loyalty. The result from multiple regressions showed significant level 0.000 for brand equity that affects brand loyalty of the bottled mineral drinking water. When broken into details, brand association and brand perceived quality significantly affect brand loyalty. As well as the combined effect of the model indicated that 52.6 percent of the total variance in brand equity affects brand loyalty of the bottled mineral drinking water.
\end{abstract}

(c) 2017 The Author(s). Published by TAF Publishing.

\section{INTRODUCTION}

Brand equity and brand loyalty are two concepts that have been delved into by researchers, as they are two very important dimensions in marketing. Brand equity is a reflection of consumers' perception towards the brand (Keller, 1993). Brand equity contributes to consumers' trust and confidence in the brand, which consequently lead to repurchase intention. In addition, brand equity increases the efficacy of marketing activities.

It facilitates marketing experts in the development of marketing strategies, while increases the competency of brand extension (Kisese, 2002), resulting in an increase in sales that further reflects the increase in market share (Kotler, 2000). Accordingly, the customer-based brand equity perspective plays an important role in the success of marketing (Aaker, 1991; Kotler \& Amstrong, 1990). Brand loyalty is when consumers have positive attitudes towards a particular brand, whether such attitudes arise from confidence, recall, or satisfaction. Brand loyalty results in consumers' attachment to the brand, as well as their repurchasing behavior.

In the presence of brand loyalty, consumers are unlikely to switch to other brands due to their love and belief for that particular brand. Likewise, they will become familiar with the brand and purchase the product with habitual behavior (Kotler \& Amstrong, 1990). Brand loyalty can be defined in terms of both purchase behavior and psychological perspective. Purchase behavior is widely used to define brand loyalty because it can be easily measured by observing the repurchasing behavior of consumers, which eventually lead to the establishment of brand loyalty (Alkhawaldeh \& Halim, 2016). Meanwhile, the psychological perspective refers to the positive attitudes and attachment of consumers towards the brand. Positive attitudes stem from

\footnotetext{
${ }^{*}$ Corresponding author: Kittipa Wichailert

†Email: kittipa_w@kkumail.com
} 
three elements, comprising of confidence, centrality, and accessibility. Any brands that encompass all three elements are likely to create positive attitudes amongst consumers, which eventually leads to brand loyalty. In addition to the establishment of strong customer base, brand loyalty also contributes to the expansion of customer base through word of mouth. At present, the market for bottled mineral drinking water in Thailand is growing at a rate of $15 \%$, with the total market value of 2,500 million Baht. The most popular brands in Thailand are Minéré, Aura, Mont Fleur, and Purra. This entices many entrepreneurs to enter the market. Indeed, there are currently a variety of brands in the market, as well as various marketing strategies that are being implemented to attract consumers to switch brands.

Accordingly, brand loyalty reflects consumers' confidence and trust in the brand, which is regarded as a key component of brand equity. If consumers could no longer differentiate between the products, it might be possible that they would switch to another brand (Aaker, 1991; Ishak \& Abd Ghani, 2013). Jacoby \& Chestnut (1978:81) and Nunnally (1978) stated that brand loyalty can be categorized into two main groups: the behavioral aspect or consumer's repurchase of the product from one or more than one brand and the attitude aspect, which refers to psychological aspect that includes evaluation and decision-making process. These two factors contribute to an increase in the consumers' attachment to the brand, which consequently leads to brand loyalty. Once brand loyalty has been established, consumers will perceive the brand in a good way and overlook all of the flaws; in other words, they will be biased towards their loyal brand. Concerning the current issues, along with the economic trend of bottled mineral water in Thailand that still attracts new businesses into the market; the researcher had conducted the study with an emphasis on examining the effects of brand equity on the brand loyalty of bottled mineral water. The researcher aimed to utilize and apply the data and research findings to the bottled mineral water business. The obtained data would be used to establish brand equity that would subsequently affect the brand loyalty on the next purchase (Geok,
1999; Severi \& Ling, 2013).

As a consequence, this would create a competitive advantage and facilitate and accelerate consumers' purchasing decision-making process, allowing the business to thrive in the market in a sustainable way. Research questions are: $\bullet$ What were the levels of brand equity and brand loyalty in the bottled mineral drinking water?

- How the characteristics of consumers affected the level of brand equity and brand loyalty in the bottled mineral drinking water?

-What were the guidelines for the development of brand equity and brand loyalty of the bottled mineral drinking water?

\section{LITERAT URE REVIEW}

Brand equity requires an extension in the context of marketing because of the differences between goods and services. Yamane (1967) noted that brand equity is more important for products than for services. According to Chaudhuri (1999), consumer-based brand equity scale is functional for processing information and building confidence in the purchase decision and for enhancing efficiency and effectiveness of marketing programs, price, profits and brand extensions, and trade leverage. In their study, they stated that the new brand equity scale is applicable, reliable, and relevant in different product categories in different cultures. They pointed out that three-and four-dimension models that comprise of brand loyalty, perceived quality, brand awareness, and brand association are valid to identify brand equity (Taylor, Celuch \& Goodwin, 2004)

\section{Brand Equity}

Brand equity can be defined as "the marketing and financial values linked with a brand's strength in the market, including actual proprietary brand assets, brand name awareness, brand loyalty, perceived brand quality, and brand associations" (Pride \& Ferrell, 2000:299). According to Lassar, Mittal \& Arun (1995), the existing literature has evaluated the brand equity from two different points of view; financial perspective and customer's perspective.

TABLE 1. The main concepts of brand equity

\begin{tabular}{|c|c|}
\hline Major Contributors & Concepts of Brand Equity \\
\hline Mahajan et al., (1994) & Customer based Brand equity can be evaluated by the level of customer's understanding. \\
\hline Farquhar (1989) & Brand equity can be changed via the changes in consumers' thoughts as they are buying a particular product. \\
\hline Aaker (1991) & Brand equity can be evaluated through brand loyalty, brand association brand awareness and perceived quality. \\
\hline Keller (1993) & Basically, there are two methods to evaluate customer based brand equity (direct \& indirect)by stressing on two elements: brand image and brand awareness. \\
\hline
\end{tabular}


Financial perspective is usually referred to the company's brand value. While, the customer's perspective appraises brand equity based on the customers' perceived brand value from the anchor of marketing decision-making (Lassar et al., 1995). Table 1 shows the main concepts of brand equity based on the extant literature review. This paper will adopt the idea of customer's perspective of brand equity from Aaker (1991). Aaker (1996) considers brand equity as an aggregate of assets and liabilities. There are five different dimensions that can create the value of brand equity, namely; brand awareness, perceived quality, brand loyalty, brand association, and proprietary brand assets (Aaker, 1996; O'brien, 2007). Considering the aspect of brand equity, if a brand has no value, it is unlikely that it will create value to its owner. Brand equity arises when the brand provides value to consumers. In other words, brand equity refers to the consumers' perception of the brand as being valuable.

It is the brand that consumers have positive attitudes and satisfaction towards the characteristics or features of the product. Indeed, brand equity can be categorized into two perspectives: financial-based brand equity perspective (Simon \& Sullivan, 1993; Kapferer, 1992) and customerbased brand equity perspective (Aaker, 1991; Keller, 1993). This research emphasized on the study of the elements of brand equity based onconsumers' perspectives towards brand loyalty on the purchase of bottled mineral water. The financial-based perspective of brand equity was not used in this research due to the availability of information regarding sales, operating profit, and market share -all of which can be obtained from the company's financial report. Hence, it was unnecessary to conduct a customers' survey to acquire such data. Accordingly, the elements of brand equity that were employed in this research include brand awareness, brand association, brand image, and brand loyalty, with details as follows:

1. Brand Awareness - Keller (1993) defined brand awareness as the ability of customers to remember and recall the brand. Upon the review of Aaker's (1996) concept, brand awareness consists of four factors, comprising of brand remembrance, brand recall, brand attachment, and brand familiarity.

A group of researchers (Yoo, Donthu \& Lee, 2000; Pappu, Quester \& Cooksey, 2006; Davis, Golicic \& Marquardt, 2008; Lee \& Leh, 2011) elaborated on such factors and used them as variables in the study of brand awareness. Jalilvand, Samiei \& Mahdavinia (2011) found that the element of brand equity in the aspect of brand awareness had an influ- ence on customers'purchase intention and loyalty.

2. Brand Association refers to the attribute of customers that associates their memories with the brand (Aaker, 1991), which corresponds to the concept of Keller (1993), who classified brand association into three major categories: attributes, benefits, and positive attitudes towards the product, resulting in customer satisfaction towards the brand. According to the concept of Aaker (1996), brand association consists of three factors, including value, brand personality, and association with the organization. A group of researchers (Yoo et al., 2000; Pappu et al., 2006; Tong \& Hawley, 2009; Lee \& Leh, 2011) developed such factors into variables in the study. Moreover, Jalilvand et al. (2011) found that the element of brand equity in the aspect of brand association had an influence on customers' purchase intention and loyalty.

3. Brand Image - the concept of brand image is regarded as one of the most important marketing concepts (Gardner \& Levy, 1955 referred by Keller, 1993). Brand image refers to consumers' perception towards the brand, which is influenced by brand association that is instilled in the consumers' memories (Gardner \& Levy, 1955 referred by Keller, 1993). In addition, Korchia (2001) asserted that human memories are stored in a network of information, whereby a single piece of information can act as a node that connects with other information. Such connection can be further used to explain the relationship between information.

Upon combining the concepts of memory and information linkage, which describe memory storage as a form of interrelated information network (Aaker, 1991), it can be inferred that brand image is anything that consumers can associate with the brand (Korchia, 2001). Accordingly, brand image can be established by imparting brand association to the long-term memory of consumers, which can retainthe brand image permanently and indefinitely (Korchia, 2001). Despite the fact that brand association plays an important role in the establishment of brand image, there were very few studies on consumers' association towards the brand (Schiffman \& Kanuk, 2010).

4. Brand Loyalty is the main pillar and the most important element of brand equity. Brand loyalty reflects customers' confidence and satisfaction towards the brand. In addition, it reduces marketing costs and prevents competitors from entering the market (Chaudhuri, 1999; Aaker, 1991). Similarly, Kisese (2002) defined brand loyalty as the positive attitudes of customers towards the brand, resulting in customers' repurchase intention upon their realization that 
the product of that particular brand corresponds to their needs, which consequently leads to customers' satisfaction. Based on the review of Aaker's (1996) concept, brand loyalty consists of four factors: high price, satisfaction, product recommendation, and loyalty. A group of researchers (Yoo et al., 2000; Tybout \& Calkins, 2005; Tong \& Hawley, 2009) used such factors to develop variables in the study. Meanwhile, Jalilvand et al. (2011) found that the element of brand equity in the aspect of brand loyalty had an influence on customers' purchase intention.

5. Brand Perceived Quality is considered as an important element of brand equity. Customers perceive the quality of brand through the quality of product, which is based on their experience. As such, brand perceived quality has a correlation with customers' purchasing decision (Aaker, 1991).

Furthermore, Villarejo-Ramos \& Sanchez-Franco (2005) stated that brand perceived quality is a concept that has been widely accepted. It is an important factor that affects customers' behaviors. The opinions of customers towards the quality of both the product attributes and brand, is a process that can be assessed through an indicator of the level of customers' perceived quality. According to Aaker (1996), brand perceived quality consists of five factors, including the level of quality, consistency of quality, market leadership, popularity, and innovation. A group of researchers (Yoo et al., 2000; Tybout \& Calkins, 2005; Tong \& Hawley, 2009) employed such factors as variables in the study; whereby Jalilvand et al. (2011) found that the element of brand equity in the aspect of brand perceived quality had an influence on customers' purchase intention and loyalty.

\section{Brand Loyalty}

Brand loyalty has received a lot of interest and has been studied by various marketing experts and scholars over the past decades. Møller Jensen \& Hansen (2006) tried to outline a concept pertaining to brand loyalty, with an emphasis on behavior rather than attitude towards brand loyalty. Meanwhile, the attitude towards brand loyalty has received more attention, considering the fact that behavioral measurement cannot truly assess all other aspects. Behavior simply relates to purchase, order of purchase, and probability of purchase of the customers (Ishak \& Abd Ghani, 2013). Brand loyalty in the aspect of behavior cannot provide an explanation to customers' repurchasing or switching behaviors (Pride \& Ferrell, 2000). Ishak \& Abd Ghani (2013) indicated that the definition of behavioral measure- ment is not sufficient to explain its effects on brand loyalty. Aaker (1991) defined brand loyalty as something that reflects consumers' confidence and attachment towards the brand. Brand loyalty is regarded as the most important element of brand equity; if consumers cannot differentiate between the products, they might be inclined to switching to the other brands. However, if consumers have high level of loyalty towards the brand, it is likely that they would purchase the product continually. Likewise, brand loyalty also contributes to consumers' repurchasing behavior. According to Aaker (1991), the measurement of brand loyalty is classified as follows:

1. Behavioral measurement is the method of assessing loyalty towards the brand. In particular, habitual behavior that takes into consideration the purchase that actually occurred, which can be measured using repurchase rate, percentage of purchase, and number of brands purchase -of which consumers may have different level of brand loyalty according to the difference in product class.

2. Attitudinal measurement is the method of measuring brand loyalty in the aspect of emotions and feelings. Consumers will express their satisfaction towards the brand through emotions and feelings. Attitudinal measurement comprises of four elements:

1.1: Switching cost - this is a measurement of costs incurred by consumers when switching to other brands.

1.2: Satisfaction - this is an important element for all levels of brand loyalty. The dissatisfaction.

of consumers may result in their deviation or inclination towards other brands.

1.3: Liking of the brand refers to consumers' perception of the brand with relation to friendship and familiarity. Liking of the brand can be categorized into liking, respect, friendship, and trust.

1.4: Commitment refers to consumers' feelings towards the brand, such as confidence and belief.

\section{Hypothesis}

Based on the research problems and conceptual framework framework, hypotheses of this research are as follows:

HO: Brand equity has no effects on brand loyalty in the purchase of bottled mineral water.

H1: Brand equity has an effects on brand loyalty in the purchase of bottled mineral water.

\section{Sub hypothesis 1}

H0: Brand equity has no effects on the attitudinal loyalty in the purchase of bottled mineral water. 
H1: Brand equity has an effects on the attitudinal loyalty in the purchase of bottled mineral water.

\section{Sub hypothesis 2}

HO: Brand equity has no effects on the behavioral loyalty in the purchase of bottled mineral water.
H1: Brand equity has an effects on the behavioral loyalty in the purchase of bottled mineral water.

\section{Conceptual Framework}

Conceptual framework of this research is shown in figure 1.

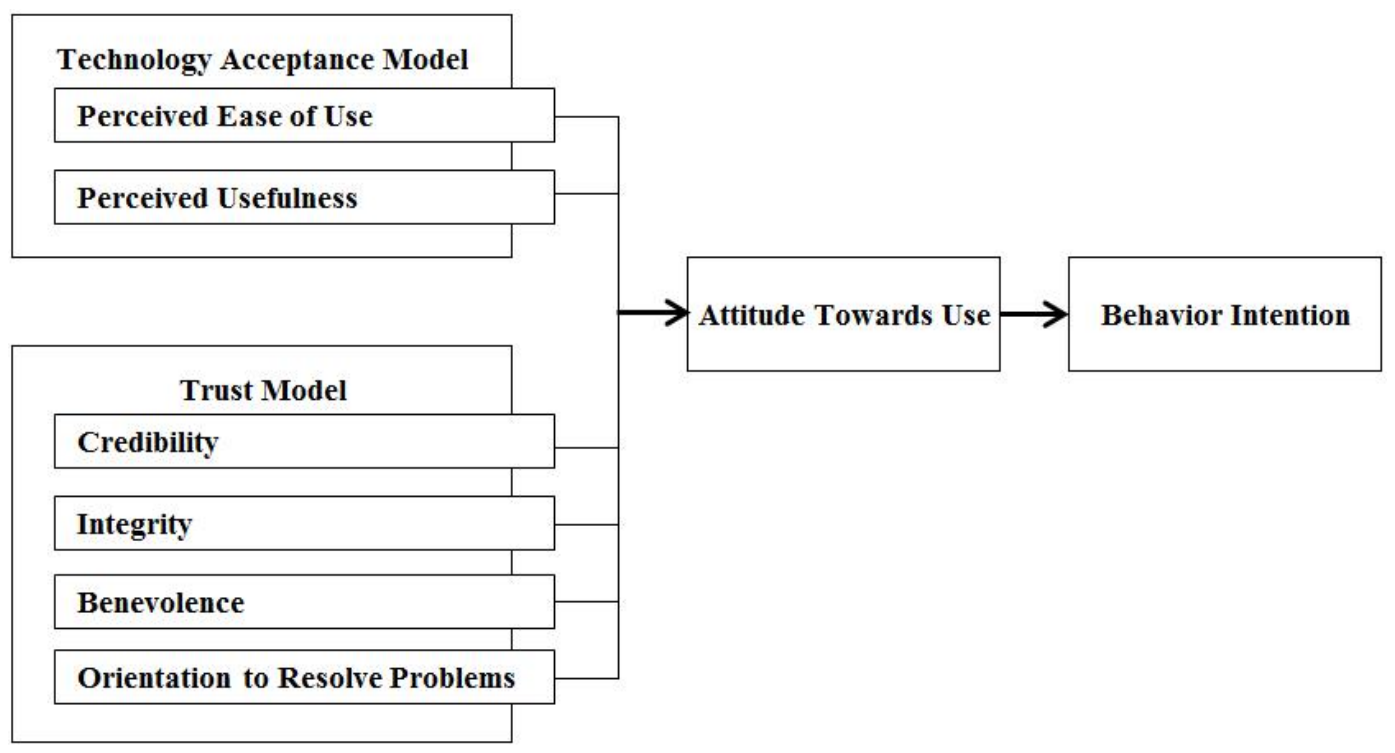

FIGURE 1. Conceptual framework

\section{RESEARCH METHOD}

This study adopted a quantitative approach by selfadministered questionnaire as a survey tool Used to quantify the relationship between independent and dependent variables based on the proposed theoretical model that delineates the relationship between independent variables of brand equity and dependents variable of brand loyalty. All data were collected from customers who drank the mineral drinking water in Thailand, during March - April 2017 in Bangkok, the capital of Thailand.

\section{Sample}

The sample respondents answered the questions by themselves. The questionnaire was divided into three sections. First section of the survey was designed to get information about demographic characteristics of the customers of the mineral drinking water in Thailand.

The second section of this survey was designed to get information of brand awareness, brand association, and perceived quality of brand on brand equity (Asif, Abbas, Kashif, Hussain \& Hussain, 2015; Sasmita \& Mohd Suki, 2015). The third section of this survey was designed to get informa- tion of attitudinal loyalty and behavioral loyalty on brand loyalty. Sample group consisted of 400 consumers who drank the bottled mineral drinking water in Thailand. Cochran (1953) stated that convenience sampling method was followed for this study.

\section{Data Analysis Procedures}

This study used SPSS version 17 (Statistic Package for Social Sciences) for calculation of statistics.

\section{Validity and Reliability}

The questionnaire was checked for validity and reliability. Thirty samples of the reliability test were given to customers before conducting the survey in order by analyzing and finding Cronbach's alpha Coefficient of reliability, which was 0.955 (Rovinelli \& Hambleton, 1976; Yamane, 1967).

\section{RESEARCH RESULTS}

Sum was 400 in this study, in terms of gender, the majority of the sample group were females, who totaled to 150 $(62.5 \%)$ and 150 were males (37.5\%). In terms of age, the majority of the sample group aged 26-35 years. total of 
$196(49.00 \%)$, followed by 19-25 years with a total of 12 (30.25\%), 36-45 years $68(17.00 \%)$, less than 18 years totaling $9(2.25 \%)$, and more than 56 years totaling 6 $(1.50 \%)$. In terms of educational background, the majority of the sample group were graduated with Bachelor's Degree, which totaled to $304(76.00 \%)$, followed by Master's Degree with a total of $73(18.25 \%)$, less than Bachelor's Degree with a total of 20 (5.00\%), and Ph.D with a total of $3(0.75 \%)$. In terms of status, the majority of the sample group were single, with a total of $304(76.00 \%)$. Meanwhile, $84(21.00 \%)$ were married and $12(3.00 \%)$ were widowed/divorced. In the aspect of occupation, the majority of the sample group were employed by a private company, which totaled to 238 (59.50\%), while 70 (17.50\%) were government officials, 66 (16.50\%) were business owners $21(5.25 \%)$ were students, and $5(1.25 \%)$ had other.

For the average monthly salary, it was found that the majority of the sample group had the average monthly salary of 10,001-20,000 Baht, totaling 187 (46.75\%), followed by 20,001-30,000 Baht, 121 (30.25\%). Meanwhile, $43(10.75 \%)$ had more than 40,000 Baht, 37 (9.25\%) had 30,001-40,000 Baht, and 12 (3.00\%) had less than10,000 Baht.

TABLE 2 . Demographic data of the sample $(N=400)$

\begin{tabular}{lccc}
\hline \hline Variables & & Frequency & $\mathbf{\%}$ \\
\hline Sex & Male & 150 & 37.5 \\
Age & Female & 250 & 62.5 \\
& Less than 18 & 9 & 2.25 \\
& $19-25$ & 121 & 30.25 \\
More than 56 & $26-35$ & 196 & 49 \\
Education & $36-45$ & 68 & 17 \\
& 6 & 1.5 & \\
& Less than Bachelor's Degree & 20 & 5 \\
Status & Bachelor's Degree & 304 & 76 \\
& Master's Degree & 73 & 18.25 \\
Occupation & PhD & 3 & 0.75 \\
Private company employee & Single & 304 & 76 \\
Own Business & Marry & 84 & 21 \\
Student & Widowed / Divorced & 12 & 3 \\
Other & Government official & 70 & 17.5 \\
Monthly Income (Bath) & 238 & 59.5 & \\
& 66 & 16.5 & \\
& 21 & 5.25 & \\
& 5 & 1.25 & \\
& Less than 10,000 & 12 & 3 \\
\hline \hline
\end{tabular}

TABLE 3 . Show the mean and standard deviation of brand equity level of bottled mineral drinking water

\begin{tabular}{lccc}
\hline \hline Brand Equity Of Mineral Drinking Water & $\begin{array}{c}\text { Level } \\
\text { Mean }\end{array}$ & S.D & Report \\
& 3.83 & 0.43 & High \\
\hline Total of Brand Awareness & 3.77 & 0.50 & High \\
Total of Brand Association & 3.81 & 0.42 & High \\
Total of Perceived Quality & & & \\
\hline \hline
\end{tabular}


TABLE 4. Show the mean and standard deviation of brand loyalty level of bottled mineral drinking water

\begin{tabular}{lccc}
\hline \hline Brand Equity Of Mineral Drinking Water & $\begin{array}{c}\text { Level } \\
\text { Mean }\end{array}$ & S.D & Report \\
& 3.77 & 0.51 & High \\
Total of Attitudinal loyalty & 3.75 & 0.50 & High \\
Total of Behavioral loyalty & & & \\
\hline \hline
\end{tabular}

Based on the survey questionnaires, the researcher assessed the scores in terms of a rating scale. The levels of the brand awareness and loyalty amongst the sample group, rated from highest, high, medium, low, and lowest, were 4.21-5.00, 3.41-4.20, 2.61-3.40, 1.81-2.60, and 1.00-1.80, respectively.

In addition, it was evident that the sample size was aware of the brand equity in the aspect of brand name at a high level, with the average of 3.83. Likewise, the awareness of brand equity in the aspects of brand association and quality perception were at a high level, with the average of 3.77 and 3.83, respectively. Meanwhile, the levels of brand loyalty in the aspects of attitude and behavior were at a high level, with the average of 3.77 and 3.75 , respectively.

\section{Hypothesis Testing}

In Hypothesis testing, given symbols of Brand Equity of Brand Awareness, Brand Association, Perceived Quality of Brand, Brand Loyalty of Attitudinal loyalty, and Behavioral loyalty were BAW, BAS, BPQ, ATT and BHV.

TABLE 5 . Output SPSS for multiple regressions analysis of brand loyalty level of bottled mineral drinking water

\begin{tabular}{lccccc}
\hline \hline $\begin{array}{l}\text { ANOVA }^{a} \\
\text { Model }\end{array}$ & Sum of Squares & df & Mean Square & $\boldsymbol{F}$ & Sig. \\
\hline Regression & 42.794 & 3 & 14.265 & 97.841 & $0.000 \mathrm{~b}$ \\
Residual & 57.735 & 396 & 0.146 & & \\
Total & 100.529 & 399 & & & \\
\hline
\end{tabular}

** a. Dependent Variable: BLO

b. Predictors: (Constant), BAW, BAS, BPQ

TABLE 6. Output SPSS for enter multiple regressions analysis of brand loyalty level of bottled mineral drinking water

\begin{tabular}{lccccc}
\hline \hline Coefficients $^{a}$ & Unstandardized Coefficients & Standardized Coefficients & & & \\
Model & $\beta$ & Std. Error & $\beta$ & $\boldsymbol{t}$ & Sig. \\
\hline (Constant) & 1.094 & 0.18 & 6.063 & 0 & \\
BAW & -0.001 & 0.06 & -0.001 & -0.019 & 0.985 \\
BAS & 0.28 & 0.063 & 0.28 & 4.433 & 0 \\
BPQ & 0.42 & 0.06 & 0.415 & 7.056 & 0 \\
\hline
\end{tabular}

a. Dependent Variable: BLO

TABLE 7. Model summary SPSS for brand equity affects from brand loyalty level of bottled mineral drinking water

\begin{tabular}{lcccc}
\hline \hline $\begin{array}{l}\text { Model Summary } \\
\text { Model }\end{array}$ & $\mathbf{R}$ & $R^{2}$ & Adjusted $R^{2}$ & Std. Error of the Estimate \\
\hline 1 & $0.652^{a}$ & 0.526 & 0.421 & 0.38183 \\
\hline \hline a. Predictors: (Constant), BAW, BAS, BPQ & &
\end{tabular}


It was found that brand equity had an influence on the loyalty in purchasing bottled mineral drinking water at $52.6 \%$ $\left(R^{2}=0.526\right)$. Based on the above equation, the coefficients of independent variables were formulated to predict the brand loyalty in purchasing bottled mineral water (BLO), using the raw score as follows: $\mathrm{BLO}=1.094-0.001 \mathrm{BAW}$ $+0.280 \mathrm{BAS}+0.420 \mathrm{BQP}$. The results can be concluded as below.

The independent variables, or the brand equity, had a positive correlation with brand loyalty in purchasing a ottled mineral drinking water (BLO) at a significance level of 0.05 . The brand equity in the aspects of brand association and quality perception determined the brand loyalty in purchasing bottled mineral drinking water (BLO). Mean- while, brand equity in the aspect of brand awareness did not determine the loyalty in purchasing bottled mineral water. The coefficients can be explained as follows: If the Brand Awareness (BAW) increased by 1 unit, it would not affect the Brand Loyalty (BLO) to decrease by 0.001 units, keeping the other two variables of brand equity constant. If the brand association (BAS) increased by 1 unit, it would affect the brand loyalty (BLO) to increase by 0.280 unit, keeping the other two variables of brand equity constant. If thebrand perception quality (BPQ) increased by 1 unit, it would affect the brand loyalty (BLO) to increase by 0.420 unit, keeping the other two variables of brand equity constant.

TABLE 8. Output SPSS for multiple regression analysis for attitudinal loyalty of bottled mineral drinking water

\begin{tabular}{lccccc}
\hline \hline $\begin{array}{l}\text { ANOVA }^{a} \\
\text { Model }\end{array}$ & Sum of Squares & df & Mean Square & $\boldsymbol{F}$ & Sig. \\
\hline Regression & 46.679 & 3 & 15.56 & 106.321 & $0.000^{b}$ \\
Residual & 57.953 & 396 & 0.146 & & \\
Total & 104.631 & 399 & & & \\
\hline \hline a. Dependent Variable: ATT b. Predictors: (Constant), BAW, BAS, BPQ & &
\end{tabular}

TABLE 9. Output SPSS for enter multiple regression analysis for attitudinal loyalty of bottled mineral drinking water

\begin{tabular}{lccccc}
\hline \hline Coefficients $^{a}$ & Snstandardized Coefficients & Standardized Coefficients & & & \\
Model & $\beta$ & Std. Error & $\beta$ & $\boldsymbol{t}$ & Sig. \\
\hline (Constant) & 0.936 & 0.181 & 5.175 & 0 & \\
BAW & 0.039 & 0.06 & 0.033 & 0.654 & 0.514 \\
BAS & 0.303 & 0.063 & 0.298 & 4.793 & 0 \\
BPQ & 0.403 & 0.06 & 0.391 & 6.763 & 0 \\
\hline
\end{tabular}

a. Dependent Variable: ATT

TABLE 10 . Model summary SPSS for brand equity affects from attitudinal loyalty of bottled mineral drinking water

\begin{tabular}{lcccc}
\hline $\begin{array}{l}\text { Model Summary } \\
\text { Model }\end{array}$ & $\mathbf{R}$ & $R^{2}$ & Adjusted $R^{2}$ & Std. Error of the Estimate \\
\hline 1 & $0.668^{a}$ & 0.446 & 0.442 & 0.38255 \\
\hline \hline a. Predictors: (Constant), $\mathrm{BAW}, \mathrm{BAS}, \mathrm{BPQ}$ & &
\end{tabular}


TABLE 11. Multiple regression analysis for behavioral loyalty of bottled water

\begin{tabular}{lccccc}
\hline \hline $\begin{array}{l}\text { ANOVA }^{a} \\
\text { Model }\end{array}$ & Sum of Squares & df & Mean Square & $\boldsymbol{F}$ & Sig. \\
\hline Regression & 39.28 & 3 & 13.093 & 60.381 & $0.000^{b}$ \\
Residual & 85.871 & 396 & 0.217 & & \\
Total & 125.151 & 399 & & & \\
\hline \hline a. Dependent Variable: BHV b. Predictors: (Constant), BAW, BAS, BPQ & &
\end{tabular}

TABLE 12. Enter multiple regression analysis for behavioral loyalty of bottled mineral drinking water

\begin{tabular}{lccccc}
\hline \hline Coefficients $^{a}$ & & & & & \\
Model & Unstandardized Coefficients & Standardized Coefficients & & & \\
\hline (Constant) & $\beta$ & Std. Error & $\beta$ & $\boldsymbol{t}$ & Sig. \\
BAW & 1.253 & 0.22 & 5.692 & 0 & \\
BAS & -0.041 & 0.073 & -0.032 & -0.567 & 0.571 \\
BPQ & 0.257 & 0.077 & 0.23 & 3.332 & 0.001 \\
\hline \hline
\end{tabular}

a. Dependent Variable: BHV

TABLE 13. Model summary for brand equity affects from behavioral loyalty of bottled mineral water

\begin{tabular}{lcccc}
\hline $\begin{array}{l}\text { Model Summary } \\
\text { Model }\end{array}$ & $\mathbf{R}$ & $R^{2}$ & Adjusted $R^{2}$ & Std. Error of the Estimate \\
\hline 1 & $0.560^{a}$ & 0.3140 .309 & 0.46567 & \\
\hline \hline a. Predictors: (Constant), BAW, BAS, BPQ &
\end{tabular}

TABLE 14. Summarize the statistical significant Level for brand equity and brand loyalty of bottled mineral drinking water

\begin{tabular}{lccc}
\hline \hline Sig. Brand Equity & & Sig. Brand Loyalty & \\
& Attitudinal Loyalty & Behavioral Loyalty & Total \\
\hline Brand Awareness & 0.514 & 0.571 & 0.985 \\
Brand Association & 0 & 0.001 & 0 \\
Perceived Quality & 0 & 0 & 0 \\
\hline \hline
\end{tabular}

It was found that brand equity had an effect on the brand loyalty in purchasing bottled mineral drinking water, in the aspect of attitude, at $44.6 \%(\mathrm{R} 2=0.446)$. Based on the above equation, the coefficients of independent variables were formulated to predict the brand loyalty in purchasing bottled mineral water in the Aspect of Attitude (ATT), using the raw score as follows: ATT $=0.936+0.039 \mathrm{BAW}$ $+0.303 \mathrm{BAS}+0.403 \mathrm{BQP}$. The results can be concluded as below.

The independent variable had a positive correlation with brand loyalty in the ATT, at a significant level of 0.05 . The brand equity in the aspects of brand association and perception quality was the factor that determined brand loyalty in the ATT. Meanwhile, brand equity in the aspect of brand awareness did not determine brand loyalty in the ATT.

The coefficients can be explained as follows: If the Brand Awareness (BAW) increased by 1 unit, it would not affect the brand loyalty in the ATT to increase by 0.039 unit, keeping the other two variables of brand equity constant. If the Brand Association (BAS) increased by 1 unit, it would affect the brand loyalty in the ATT to increase by 0.303 unit, keeping the other two variables of brand equity constant. If the Brand Perception Quality (BQP) increased by 1 unit, it would affect the brand loyalty in the ATT to increase by 0.403 unit, keeping the other two variables of brand equity 
constant. It was found that the significant value of $0.000 \mathrm{in}$ dicated that the brand loyalty in purchasing bottled mineral water, in the aspect of behavior, had a significance level of 0.05 and the linear assumption can be illustrated as follows.

According to Table 12, it was evident that the brand equity, in the aspects of brand awareness, brand association, and brand perception quality, had an influence on the brand loyalty in the aspect of behavior, at a significant level of 0.05 . According to Table 13, it was found that brand equity had an effect on the brand loyalty, in the aspect of behavior, at $31.4 \%(\mathrm{R} 2=0.314)$. Based on the above equation, the coefficients of the independent variables were formulated to predict the brand loyalty in the aspects of behavior (BHV), using the raw score as follows: $\mathrm{BHV}=1.253-0.041 \mathrm{BAW}$ $+0.257 \mathrm{BAS}+0.437 \mathrm{BQP}$. The results can be concluded as below.The independent variables had a positive correlation with brand loyalty in the aspect of behavior (BHV) at a significance level of 0.05 . The brand equity in the aspects of brand association and brand perception quality was the factor that determined the brand loyalty in the aspect of behavior (BHV). Meanwhile, the brand equity in the aspect of brand awareness did not determine the brand loyalty in the aspect of behavior (BHV). The coefficients can be explained as follows: If the brand awareness (BAW) increased by 1 unit, it would not affect the brand loyalty in the aspect of behavior (BHV) to decrease by 0.041 unit, keeping the other two variables of brand equity constant. If the brand association (BAS) increased by 1 unit, it would affect the brand loyalty in the aspect of behavior (BHV) to increase by 0.257 unit, keeping the other two variables of brand equity constant. If the brand perception quality (BPQ) increased by 1 unit, it would affect the brand loyalty in the aspect of behavior (BHV) to increase by 0.437 unit, keeping the other two variables of brand equity constant.

\section{DISCUSSION}

The findings of this research show that the independents and dependent variables showed a correlation between brand equity and brand loyalty. Another finding shows that brand association and perceived quality of brand equity influence brand loyalty, both in terms of attitude and behavior. But brand awareness on brand equity. There was no influence on brand loyalty; both in terms of attitude and behavior. This is in line with the concept model from (Aaker, 1996). There are five different dimensions that can create the value of brand equity, namely; brand awareness, perceived quality, brand loyalty, brand association and proprietary brand assets. Compared with the research which has been done by Kisese (2002) similarity is in the research of the determinants of brand equity in the bottled drinking water industry in Nairobi. Researcher had a bearing in influencing each of the four aspects of brand equity (Brand Awareness, Brand Loyalty, Brand Associations, and Brand Perceived Quality). Respondents were then required to rate each of these factors on a five-point Likert scale with rating ranging from very important (5) to not important at all (1). That shows Product differentiation, effective brand communications, word of mouth communications, quality assurance, and effective distribution are important factors in influencing brand awareness.

Augmented product, and product liability, effective distribution, positive associations, effective brand communications, and price differentiation are important factors that enhance brand loyalty in the industry. Organizational associations, brand value associations and personality associations are important factors in enhancing brand associations in the industry. Quality attainment and organizational image, service that comes with the brand, brand value proposition and effective brand communications are important factors that enhance brand perceived quality in the industry. Compared with the research which has been done by Loureiro \& Miranda (2011) and Kotler (2000) similarity is in the research of the determinants of brand equity and brand loyalty in the internet banking context: FIMIX-PLS market segmentation. This research presents a model that integrates trust, online risks and benefits, brand awareness/associations, perceived quality, and explains how they impact brand equity and brand loyalty in the context of internet banking.

The research findings show that the main difference characterizing the two uncovered customer segments lies in the place of residence. Thus, the impact of online benefits on trust in the service provided is stronger for the first segment than for the second. For customers of the second segment, confidence in the bank's website information leads to a better perception of service quality and this is very important to ensure loyalty to the brand.

\section{CONCLUSION \& RECOMMENDATIONS}

Based on the hypothesis and the result of the research, the conclusions of this research are as follows:

- First hypothesis stated that brand equity has significant influence on brand loyalty.

- Second hypothesis stated that brand equity has significant influence of attitudinal loyalty on brand loyalty.

- Third hypothesis stated that brand equity has significant 
influence of behavioral loyalty on brand loyalty.

Based on those conclusions, therefore, recommendations of this research are:

- Since brand equity is an important factor of marketing success, brand equity will enable the differentiation of your products or services from other competitors. In addition, it will help consumers remember the products or services that they are satisfied or impressed with, which consequently affects their repurchasing behavior. As such, business owners or entrepreneurs should emphasize on establishing brand equity.

Once brand equity has been successfully established, it must be maintained because in the end, good brand equity will provide some form of guarantee to the business that it can be continuously and sustainably operated, both at present and in the future. Accordingly, it is important to make the elements of the independent variable (brand equity) be in correlation with the elements of dependent variable (brand loyalty), as stipulated by the researcher.

- In the aspect of brand loyalty, it arises from consumers' attitudes towards a particular brand, including confidence, recollection, satisfaction, and all the way to the tendency to repurchase that particular product continuously -all of which are considered as part of the marketing strategy. Each business should put emphasis on establishing the brand loyalty, similar to the brand equity. With successful creation of brand loyalty, consumers will have positive attitudes towards the brand, which ultimately induce their purchasing behavior, as well as repurchasing behavior. As a consequence, the company will have a solid customer base, which may further result in the word of the mouth and the increase in number of customers.

- According to this research, the researcher had conducted the study and collected data for a period of three months, which may be regarded as a limitation in the aspect of time. Therefore, the subsequent research should be conducted for a longer period of time, which might enable a more detailed and clearer information to be collected.

\section{REFERENCES}

Aaker, D.A. 1991. Managing brand equity: Capitalizing on value of a brand name. New York, NY: The Free Press. Aaker, D.A. 1996. Building strong brands. New York, NY: The Free Press.

Alkhawaldeh, A.M., \& Halim, F.B. 2016. Brand equity and brand loyalty: New perspective. International Review ofMan- agement \& Marketing, 6(4): 722-730.

Asif, M., Abbas, K., Kashif, M., Hussain, S., \& Hussain, I. 2015. Impact of brand awareness and loyalty on brand equity. Journal of Marketing \& Consumer Research, 2(4): 2422-8451.

Chaudhuri, A. 1999. Does brand loyalty mediate brand equity outcomes? Journal of Marketing Theory \& Practice, 7(2): 136-146. DOI: 10.1080/10696679.1999.11501835

Cochran, W.G. 1953. Sampling techiques. New York, NY: John Wiley \& Sons.

Davis, D.F., Golicic, S.L., \& Marquardt, A.J. 2008. Branding a B2B service: Does a brand differentiate a logistics service provider? Industrial Marketing Management, 37(2): 218-227.

Gardner, B.B., \& Levy, S.J. 1955. The product and the brand. Harvard Business Review, 33(2): 33-39.

Geok, T.L. 1999. Consumers trust in a brand and the link to brand loyalty. Singapore, SG: Public of Singapore.

Ishak, F., \& Abd Ghani, N.H. 2013. A review of the literature on brand loyalty and customer loyalty. Unpublished doctoral dissertation, College of Business Universiti Utara Malaysia Sintok, Changlun, MY.

Jacoby, J., \& Chestnut, R.W. 1978. Brand loyalty: Measurement and management. New York, NY: John Wiley \& Son. Kapferer, J.N. 1992. Strategic brand management: New approaches to creating and evaluating Brand equity. London, UK: Kogan.

Jalilvand, M.R., Samiei, N., \& Mahdavinia, S.H. 2011. The effect of brand equity components on purchase intention: An appli- $\quad$ cation of Aaker's model in the automobile industry. International Business \& Management, 2(2): 149-158.

Keller, K.L. 1993. Conceptualizing, measuring, and managing customer-based brand equity. The Journal of Marketing, 57(1): 1-22.

Kisese, E.W. 2002. The determinants of brand equity in the bottled drinking water industry in Nairobi. Unpublished MBA Project, University of Nairobi, Kenya, KE.

Korchia, M. 2001. The dimensions of brand familiarity. Paper presented at the 30th Eurpean Marketing Academy, Bergen, NO.

Kotler, P., \& Amstrong, G. 1990. Market an introduction. New Jersey, NJ:Prentice-Hall. 
Kotler, P. 2000. Marketing Management : Anaiysis, planning implementation and control. New Jersy, NJ: Prentice-Hall Inc.

Lassar, W., Mittal, B., \& Sharma, A. 1995. Measuring customer-based brand equity. Journal of Consumer Marketing, 12 (4): 11-19.

Lee, G.C., \& Leh, F.C.Y. 2011. Dimensions of customer-based brand equity: A study on Malaysian brands. Journal of Market- $\quad$ ing Research \& Case Studies, 2(3): 1-10.

Loureiro, S.M.C., \& Miranda, F.J. 2011. Brand equity and brand loyalty in the internet banking context: FIMIX-PLS market segmentation. Journal of Service Science \& Management, 4(04): 476-480. D0I: 10.4236/jssm.2011.44054

Møller Jensen, J., \& Hansen, T. 2006. An empirical examination of brand loyalty. Journal of Product \& Brand Manage- $\quad$ ment, 15(7): 442-449.

Nunnally, J.C. 1978. Psychometric theory. New York, NY: McGraw-Hill Book Company.

O’brien, R.M. 2007. A caution regarding rules of thumb for variance inflation factors. Quality \& Quantity, 41(5): 673-690. DOI: $10.1007 / s 11135-006-9018-6$

Pappu, R., Quester, P.G., \& Cooksey, R.W. 2006. Consumer-based brand equity and country-of-origin relationships: Some empirical evidence. European Journal of Marketing, 40(5/6): 696-717.

Pride, W.M., \& Ferrell, O.C. 2000. Marketing concepts and strategies. Boston, MA: Houghton Mifflin.

Rovinelli, R.J., \& Hambleton, R.K. 1976. On the use of content specialists in the assessment of criterion-referenced test item validity. Dutch Journal of Educational Research, 2: 49-60.

Sasmita, J., \& Mohd Suki, N. 2015. Young consumers' insights on brand equity: Effects of brand association, brand loyalty, brand awareness, and brand image. International Journal of Retail \& Distribution Management, 43(3): $276-292$. DOI: $10.1108 / I J R D M-02-2014-0024$

Schiffman, L., \& Kanuk, L.L. 2010. Consumer behaviour. United State of America, US: Peason Education Inc.

Severi, E., \& Ling, K.C. 2013. The mediating effects of brand association, brand loyalty, brand image and perceived quality on brand equity. Asian Social Science, 9(3): 125-130. D0I: 10.5539/ass.v9n3p125

Simon, C.J., \& Sullivan, M.W. 1993. The measurement and determinants of brand equity: A financial approach. Marketing Science, 12(1): 28-52. DOI: $10.1287 / \mathrm{mksc} .12 .1 .28$

Taylor, S.A., Celuch, K., \& Goodwin, S. 2004. The importance of brand equity to customer loyalty. Journal of Product \& Brand Management, 13(4): 217-227. DOI: 10.1108/10610420410546934

Tong, X., \& Hawley, J.M. 2009. Measuring customer-based brand equity: Empirical evidence from the sportswear market in China. Journal of Product \& Brand Management, 18(4): 262-271.

Tybout, A.M., \& Calkins, T. 2005. Kellogg on branding. Nova Jersey, NJ: John Wiley \& Sons Inc.

Villarejo-Ramos, A.F., \& Sanchez-Franco, M.J. 2005. The impact of marketing communication and price promotion on brand equity. Journal of Brand Management, 12(6): 431-444.

Yamane, T. 1967. Statistics: An introductory analysis. New York, NY: Harper and Row Publication.

Yoo, B., Donthu, N., \& Lee, S. 2000. An examination of selected marketing mix elements and brand equity. Journal of the Academy of Marketing Science, 28(2): 195-211.

— This article does not have any appendix. - 